\title{
Pengembangan Modul Ajar Akuntansi Perpajakan di Jurusan Akuntansi Politeknik Negeri Sriwijaya
}

\author{
Muhammad Husni Mubarok ${ }^{1)}$, Darul Amri' ${ }^{2}$, Nurhasanah ${ }^{3)}$ \\ 1), 2),3) Jurusan Akuntansi Politeknik Negeri Sriwijaya \\ mhusnimubarok@polsri.ac.id \\ darulamri2005@gmail.com \\ fatihfauziakbar@yahoo.co.id
}

\begin{abstract}
Human resources in companies that understand accounting and tax become indispensable. The accounting department is a formal education provider of accounting services, this is the need to equip students to get a good understanding of tax accounting. The problem is learning in the accounting department, that are no tax or accounting courses accounting topics. In the current accounting curriculum, the curriculum is only the focus of finance generally and have not touched tax accounting. The team has implemented a service program in partnership with the accounting department in solving the problem. This program is aimed at increasing the competency and insight of students majoring in accounting, especially recording tax transactions. The training method was conducted face-to-face and frequently asked questions related to the technical recording of tax transactions. The training was attended by 53 participants from 3 invited classes. Overall this training has been performing well. From these activities that students can understand that a transaction tax is a part of the transaction recorded by the accounting department.
\end{abstract}

Kata Kunci: Akuntansi Perpajakan, Pajak Penghasilan, Pajak Pertambahan Nilai,

\section{PENDAHULUAN}

Saat ini aspek perpajakan ada dalam setiap aktivitas keuangan organisasi baik itu sektor swasta maupun sektor publik. Setiap transaksi keuangan mengandung unsur perpajakan. Pembelian barang kena pajak yang dilakukan oleh setiap orang pribadi atau perusahaan wajib membayar pertambahan nilai, begitu juga sebaliknya setiap pengusaha kena pajak yang melakukan transaksi penjualan barang wajib memungut PPN. Atau WP badan atau perorangan yang memperoleh keuntungan pada akhir tahun wajib membayar dan melaporkan pajaknya. Lebih lanjut pembayaran atas pembelian barang yang dilakukan oleh bendahara pemerintah wajib memungut PPN. Bendahara pemerintah, BUMN, pemberi kerja, yayasan, koperasi, dana pensiun yang membayarkan penghasilan kepada orang pribadi berupa gaji kepada pegawai atau uang pensiun kepada pensiunan ditunjuk sebagai pemungut pajak penghasilan pasal 21 dan wajib disetor oleh pemungut ke kas negara. Singkatnya apapun organisasinya sepanjang ada aliran uang dapat menjadi obyek pajak.

Di dalam UU Perpajakan No. 28 tahun 2007 tentang Ketentuan umum dan tatacara perpajakan. Setiap subyek pajak diwajibkan untuk menghitung sendiri, membayar dan melaporkan sendiri kewajiban perpajakannya. Jumlah pajak yang dihitung berdasarkan bukti transaksi dan pembukuan wajib pajak.

Pembukuan menjadi sarana bagi peugas pajak untuk menguji kepatuhan atas perhitungan pajak yang dilakukan oleh wajib pajak. Ketersediaan catatan akuntansi dan bukti 
transaksi yang memadai akan memudahkan pemeriksa pajak untuk mencocokkan kesesuaian antara perhitungan pajak dengan pembukuan dan bukti transaksi. Pembukuan mencerminkan transaksi yang telah direkam berdasarkan bukti transaksi, sehingga setiap perusahaan atau organisasi wajib memiliki sistem akuntansi. Sistem akuntansi dimulai dari pencatatan, pemindahbukuan dan pengikhtisaran sehingga menjadi laporan keuangan yang memenuhi ketentuan perpajakan.

Mata kuliah akuntansi yang ada saat ini lebih fokus mempelajari akuntansi keuangan secara umum belum sampai pada pembukuan dengan aspek perpajakan secara komprehensif. Padahal UU Perpajakan mewajibkan setiap wajib pajak untuk memiliki pembukuan atau laporan keuangan yang memadai termasuk pencatatan terkait dengan aspek perpajakan seperti pajak dibayar dimuka, piutang pajak, utang pajak penghasilan dsbnya.

Berdasarkan situasi di atas, tim berinisiatif untuk membekali mahasiswa jurusan akuntansi untuk mempelajari akuntansi perpajakan sehingga diharapkan dapat meningkatkan daya saing dan kompetensi mahasiswa jurusan akuntansi melalui "PENGEMBANGAN MODUL AJAR AKUNTANSI PERPAJAKAN DI JURUSAN AKUNTANSI POLITEKNIK NEGERI SRIWIJAYA".

\section{IDENTIFIKASI MASALAH}

Mata kuliah akuntansi adalah matakuliah inti dan merupakan mata kuliah keahlian di jurusan akuntansi diberikan pada semester 1, 2, 3, 4, 5 dan 6 yakni Akuntansi keuangan pengantar 1, Akuntansi keuangan pengantar 2, Akuntansi Keuangan Menengah 1, Akuntansi Keuangan Menengah 2, Akuntansi Keuangan Lanjutan 1, Akuntansi Keuangan Lanjutan 2 beserta mata kuliah praktikum.

Berdasarkan hasil pengamatan pada SAP/ Silabus pada topik mata kuliah akuntansi di atas dan diskusi dengan dosen pengasuh mata kuliah akuntansi, tim menyimpulkan topik transaksi yang mengandung unsur perpajakan belum diajarkan dikarenakan keterbatasan waktu dalam pembelajaran mata kuliah akuntansi keuangan di atas.

\section{METODOLOGI PELAKSANAAN}

Program pengembangan modul ini melibatkan dosen jurusan akuntansi dan mahasiswa di jurusan akuntansi sebagai tim pelaksana. Keterlibatan mahasiswa dalam program ini bertujuan untuk membantu tim dosen dalam menyiapkan dan melaksanakan program. Selain itu, program ini diharapkan dapat menambah pengetahuan dan pengalaman tim mahasiswa dalam mengelola tugas secara berkelompok, serta secara transfer knowledge terutama bidang perpajakan.

\section{Tahap persiapan program Pengabdian}

Program ini bekerjasama dengan jurusan akuntansi Politeknik Negeri Sriwijaya. Sebelum pelaksanaan, tim akan melakukan diskusi dan membuat kesepahaman kedua belah pihak serta meminta dukungan jurusan dalam menyukseskan progam ini yang akan tertuang dalam pernyataan kesanggupan jurusan sebagai mitra program ini.

Selanjutnya, pada tahap persiapan tim dosen akan melakukan persiapan sebagai berikut:
a. jadwal dan tempat pelaksanaan di jurusan akuntansi
b. materi dalam bentuk presentasi
c. menyusun serta menyiapkan studi kasus
d. menyusun bahan ajar akuntansi perpajakan.
e. Pendaftaran peserta

\section{Tahap pelaksanaan program Pengabdian}

Adapun pelaksanaan program pengabdian ini adalah sebagai berikut:

a. Pemaparan aturan dan konsep, teknis pencatatan transaksi perpajakan.

b. Pemaparan studi kasus, transaksi dan pencatatan transaksi pajak ke dalam jurnal

c. Diskusi, Tanya jawab dan latihan soal 


\section{Tahap evaluasi dan pelaporan program pengabdian}

Adapun pada tahap pelaporan program pengabdian ini tim akan menyusun laporan dan evaluasi program dan menyerahkan hardcopy laporan kepada lembaga.

\section{HASIL DAN PEMBAHASAN}

Tim menjelaskan hubungan antara pajak dan akuntansi, bahwa transaksi pajak merupakan transksi yang dicatat oleh bagian akuntansi. Adapun akun-akun pajak dalam laporan keuangan adalah sebagai berikut:

Aset:

1. Piutang PPN

2. Piutang $P P h$

3. PPN Masukan

4. Uang Muka PPh 22/23/24/25

Kewajiban:

1. Utang PPN

2. PPN Keluaran

3. Utang PPh Pasal 29

4. Utang PPh $22 / 23 / 24 / 25 / 26$

Beban :

1. Beban PPh Final

2. Beban Pajak Kini

3. Beban Pajak Tangguhan

\section{Pengertian}

Piutang PPN adalah akun PPN lebih bayar, akun ini muncul saat penyesuaian akhir masa pajak (bulan).

Utang PPN adalah akun PPN Kurang Bayar, akun ini muncul saat penyesuaian akhir masa pajak (bulan).

PPN Keluaran adalah akun PPN yang dipungut oleh PKP yang melakukan penyerahan.

PPN masukan adalah akun PPN yang dibayar saat perolehan BKP/JKP yang dapat dikreditkan oleh PKP.

Uang Muka PPh Pasal 22 adalah akun Pajak Penghasilan yang dibayar oleh WP atas kegiatan yang terutang $\mathrm{PPh}$ pasal 22 merupakan kredit pajak pada tahun berjalan.

Utang PPh Pasal 22 adalah akun pajak penghasilan yang dipungut oleh Pemungut $\mathrm{PPh}$ Pasal 22 tetapi belum disetor ke kas negara.
Uang Muka PPh Pasal 23 adalah akun Pajak Penghasilan yang dibayar melalui pihak lain (pemotong PPh pasal 23) merupakan kredit pajak pada tahun berjalan.

Utang PPh Pasal 23/26 adalah akun pajak penghasilan yang dipotong oleh pihak lain (Pemotong PPh Pasal 23/26) tetapi belum disetor ke kas negara.

Uang Muka PPh Pasal 24 adalah akun Pajak Penghasilan yang dibayar melalui pihak lain di luar negeri merupakan kredit pajak pada tahun berjalan di Indonesia.

Uang Muka PPh Pasal 25 adalah angsuran pajak penghasilan dibayar sendiri oleh WP Dalam Negeri selama tahun berjalan.

Beban PPh Final adalah akun Pajak Penghasilan final yang dibayar melalui pihak lain (Pemotong) dan bukan merupakan kredit pajak pada tahun berjalan.

Utang PPh Final adalah akun pajak penghasilan yang dipotong oleh pihak lain (Pemotong PPh Final) tetapi belum disetor ke kas negara.

Beban Pajak Kini adalah akun Pajak Penghasilan Pasal 17 yang terutang pada tahun berjalan.

Piutang $\mathrm{PPh}$ (pasal 28) adalah akun pajak penghasilan/ $\mathrm{PPh}$ lebih bayar pada akhir tahun pajak dimana Beban Pajak Kini < Uang Muka/Kredit pajak tahun berjalan.

Utang PPh (pasal 29) adalah akun pajak penghasilan/ $\mathrm{PPh}$ Kurang bayar pada akhir tahun pajak dimana Beban Pajak Kini > Uang Muka/Kredit pajak tahun berjalan.

Secara umum, Akuntansi Perpajakan terdiri dari :

1. Akuntansi PPN

a. Saat penyerahan BKP/JKP

1. Ekspor

2. Penyerahan dalam negeri

(PPNnya dipungut sendiri, Dipungut oleh

Pemungut, Tidak dipungut, Dibebaskan)

b. Saat Perolehan BKP/JKP.

c. Kegiatan membangun sendiri.

d. Saat akhir periode-penyesuaian bagi PKP. 
2. Akuntansi Pajak Penghasilan

a. Akuntansi Pemotongan/ Pemungutan Pajak Penghasilan Pasal 21/22/23/26/4 ayat 2 (PPh final) b. Akuntansi Pajak Penghasilan Pada Akhir Tahun

\section{Akuntansi Pajak Pertambahan Nilai}

\section{Contoh kasus penyerahan BKP/JKP}

Tgl 1 Jan 2016 PT. X menyerahkan produk elektronik kepada PT. ABC senilai Rp. 200 belum termasuk PPN, syarat penjualan $\mathrm{n} / 30$.

Jurnal
(D) Piutang Usaha
Rp. 220.000
(K) Penjualan
Rp. 200.000
(K) PPN keluaran
Rp. 20.000

Tgl 2 Jan 2016 menyerahkan produk elektronik kepada bendahara dinas P senilai Rp.330juta termasuk PPN. Ditagih tgl 10 Jan 2016.
(D) Piutang Usaha
Rp. 300.000
(K) Penjualan
Rp. 300.000

Jurnal tgl 10 Jan 2016
(D) Kas
Rp. 300.000
(D) Uang muka PPh 22
Rp. $\quad 4.500$
(K) Piutang Usaha
Rp. 295.500

\section{Contoh kasus perolehan BKP/JKP melalui Impor}
1. Cost
\$. 100.000
2. Insurance
\$. 2.000
3. Freight
$\$ .000$
Jumlah CIF
$\$ .110 .000$
4. Bea Masuk
(20\% x CIF) $\$ 22.000$
$\begin{array}{ll}\text { Nilai Impor }(\$) & \$ 132.000 \\ \text { Kurs KMK Rp } & \text { Rp. } 11.000\end{array}$
Nilai Impor Rp. 1.452.000.000 
PPh pasal 22= 2,5\% x 1.452.000.000 $(\mathrm{API})=$ Rp.36.300.000

$P P N=10 \% \times 1.452 .000 .000=$ Rp.145.200.000

Bea Masuk= Rp. $11.000 \times \$ 22.000=$ Rp. 242.000.000

Kas Keluar $=\mathbf{R p . 4 1 2 . 5 0 0 . 0 0 0}$

Perolehan Mesin

Kurs transaksi Rp. 12.000

Harga Perolehan Mesin-Akuntansi

$\mathrm{CIF}=110.000 \mathrm{x} 12.000 \quad=1.320 .000 .000$

$\mathrm{BM}=22.000 \times 11.000 \quad=242.000 .000$

Total $\quad=1.562 .000 .000$

\section{Jurnal transaksi}

$\begin{array}{ll}\text { (D) Mesin } & \text { Rp. } 1.562 .000\end{array}$

$\begin{array}{ll}\text { (D) PPN Masukan } & \text { Rp. } 145.200\end{array}$

(D) Uang Muka PPh $22 \quad$ Rp. 36.300

$\begin{array}{ll}\text { (K) Kas } & \text { Rp. } 412.500\end{array}$

(K) Utang Usaha Rp.1.320.000

3. Contoh kasus perolehan BKP/JKP melalui Pembelian yang PPNnya dapat dikreditkan dengan PPNnya yang tidak dapat dikreditkan.

1 Jan 2017 PT. ABC beli secara n/30 kotak kemasan dari PT. Kotak senilai Rp. 150juta belum termasuk PPN (FP: 010.17.xxxxxxx20)

Jurnal yang dicatat PT ABC sbb:
(D) Persediaan
150.000 .000
(K) PPN Masukan
15.000 .000
(K)Utang Usaha
Rp.165.000.000 
15 jan 2017 PT. ABC beli secara tunai kendaraan pickup dari PT. Dealer ITU senilai Rp. 120juta belum termasuk PPN (FP: 010.17.xxxxxxx75)

Jurnal yang dicatat PT ABC sbb:

(D) Kendaraan $\quad 120.000 .000$

(K) PPN Masukan $\quad 12.000 .000$

(K) Kas Rp. 132.000 .000

PT. ABC beli secara tunai meja bilyard Kantor dari Toko Spot senilai Rp. 25juta belum termasuk PPN (FP: 010.17.xxxxxxx04)- PPNnya tidak dapat dikreditkan

$\underline{\text { Jurnal yang dicatat PT ABC sbb: }}$

(D) Inventaris $\quad 27.500 .000$

(K) Kas Rp.27.500.000

30 Jan 2017 PT. ABC beli secara tunai sedan direktur dari PT Astro senilai Rp. 350juta belum termasuk PPN (FP: 010.17.xxxxxxx15). PPNya tidak dapat dikreditan

Jurnal yang dicatat PT ABC sbb:

(D) Kendaraan $\quad 385.000 .000$

(K) Kas Rp.385.000.000

30 Jan 2017 PT. ABC membangun sendiri gudang yang belum selesai dengan luas 500m2, selama januari biaya pembangunan Rp. 200juta.

Jurnal yang dicatat PT ABC pada saat setor PPN KMS sbb:

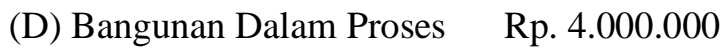

(K) Kas Rp. 4.000 .000

(PPN KMS $=10 \%$ x 20\% x Rp200juta=Rp.4juta)

\section{Contoh kasus Penyesuaian PPN KB/LB pada akhir periode}

Misal, pada akhir Januari 2018 Buku besar PPN Keluaran dan masukan sebagai berikut:

- PPN Keluaran Rp. 100.000.000

- Buku besar PPN masukan Rp.70.000.000 
Maka jurnal penyesuaiannya adalah

(D) PPN keluaran Rp. 100.000
(K) PPN masukan
Rp. 70.000
(K) Utang PPN
Rp. 30.000

\section{Akuntansi Pajak Penghasilan}

1. Contoh kasus dan jurnal transaksi pajak penghasilan pasal 21

Tanggal 1 Januari 2016, PT. ABC membayar pesangon kepada Bapak Hendra (K/3) punya NPWP yang habis masa kerjanya sebesar Rp.100juta.

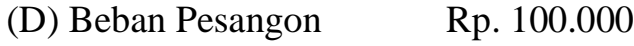

(K) Kas Rp. 97.500

(K) Utang PPh $21 \quad$ Rp. 2.500

Tanggal 2 Januari 2016, PT. ABC membayar jasa teknik pemeliharaan AC kepada Tuan Bayu (K/3) tidak punya NPWP sebesar Rp.4juta.

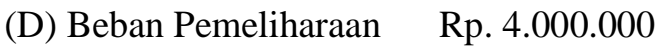

(K) Kas $\quad$ Rp. 3.880 .000

(K) Utang PPh $21 \quad$ Rp. $\quad 120.000$

Tanggal 20 Januari 2016, PT. ABC membayar hadiah uang tunai sebesar Rp. 5juta kepada pemenang lomba lari $10 \mathrm{Km}$ Gilang (TK/0) tidak punya NPWP memperingati hari Ultah Perusahaan.

(D) Beban Promosi R. 5.000 .000

(K) Kas Rp. 4.700 .000

(K) Utang PPh $21 \quad$ Rp. 300.000

Tanggal 31 Januari 2016, perusahaan membayar gaji kepada pegawai tetap sebanyak 30 orang dengan total penghasilan bruto sebesar Rp.234juta, salah satunya kepada Bapak Azzam K/1 (punya NPWP) dengan gaji pokok 10juta, tunjangan transport/bulan Rp.2juta, uang makan Rp.1,5juta, tunjangan telekomunikasi sebesar Rp.1juta. Premi Assuransi kecelakaan dan 
kematian yang dibayar oleh perusahaan sebesar 3\% dari gaji pokok. Perusahaan mengikut sertakan pegawainya dalam program pension. Iuran pension yang dibayar oleh pegawai sebesar $3 \%$ dari Gapok.

D) Beban Gaji dan Tunj. $\quad$ Rp. 14.800 .000

(K) Kas Rp. 13.342 .000

(K) Utang PPh $21 \quad$ Rp. 1.158 .000

(K) Utang Iuran Pensiun/BPJS $\quad$ Rp. 300.000

2. Contoh kasus dan jurnal transaksi pajak penghasilan pasal 22

Tanggal 8 April 2012 Menyerahkan tagihan kepada Pemkot Palembang atas penjualan sepeda motor sebanyak 2 unit dengan harga/unit sebesar Rp. 10juta belum termasuk PPN.
(D)
Piutang
Rp. 20.000
(K)
Pendapatan
Rp. 20.000

Diterima pembayaran dari Pemkot Palembang tanggal 9 April 2012.
(D)
Kas
Rp. 19.700
(D)
Uang Muka PPh 22
Rp. $\quad 300$
(K)
Piutang
Rp. 20.000

$(1,5 \%$ x 20 jtua $=$ Rp.300.000)

\section{Contoh kasus dan jurnal transaksi pajak penghasilan pasal 23/ 4 ayat 2}

Tanggal 11 April 2012 membayar Deviden kepada para pemegang saham atas laba tahun 2011;

a. PT. Alkadzim sebesar Rp. 500juta (50\% kepemilkan saham)

b. PT. Putra sebesar Rp. 200juta (20\% kepemilikan saham)

c. Tuan Abdillah sebesar Rp.300juta ( 30\% kepemilikan saham)

(D) Utang Deviden Rp. 1.000 .000
(K) Kas
Rp. 940.000
(K) $\quad$ Utang PPh 23
Rp. $\quad 30.000$
(K) Utang PPh final 4 ayat 2
Rp. $\quad 30.000$ 
Tanggal 10 April 2012 Menerima uang sewa Ruko dari PT. Chiki sebesar Rp. 12juta untuk 1 tahun ke depan.
(D) Kas
Rp. 10.800
(D) Beban PPh final
Rp. 1.200
(K) Pendapatan Sewa Diterima Dimuka
Rp. 12.000

\section{Contoh kasus akuntansi pajak penghasilan pada akhir tahun}

Akuntansi Pajak Penghasilan pada akhir tahun, bertujuan mencatat transaksi berikut:

1. Beban Pajak Kini

2. Pengkreditan Uang Muka PPh

3. Piutang $\mathrm{PPh} / \mathrm{Utang} \mathrm{PPh}$ Badan

(Piutang PPh: Beban Pajak Kini < Kredit PPh)

(Utang PPh: Beban Pajak Kini > Kredit PPh)

\begin{tabular}{l} 
PT. A \\
$\begin{array}{l}\text { Laba Rugi } \\
\text { Tahun 2015 }\end{array}$ \\
\hline
\end{tabular}

Gambar 1 Ilustrasi Laba rugi komersil 


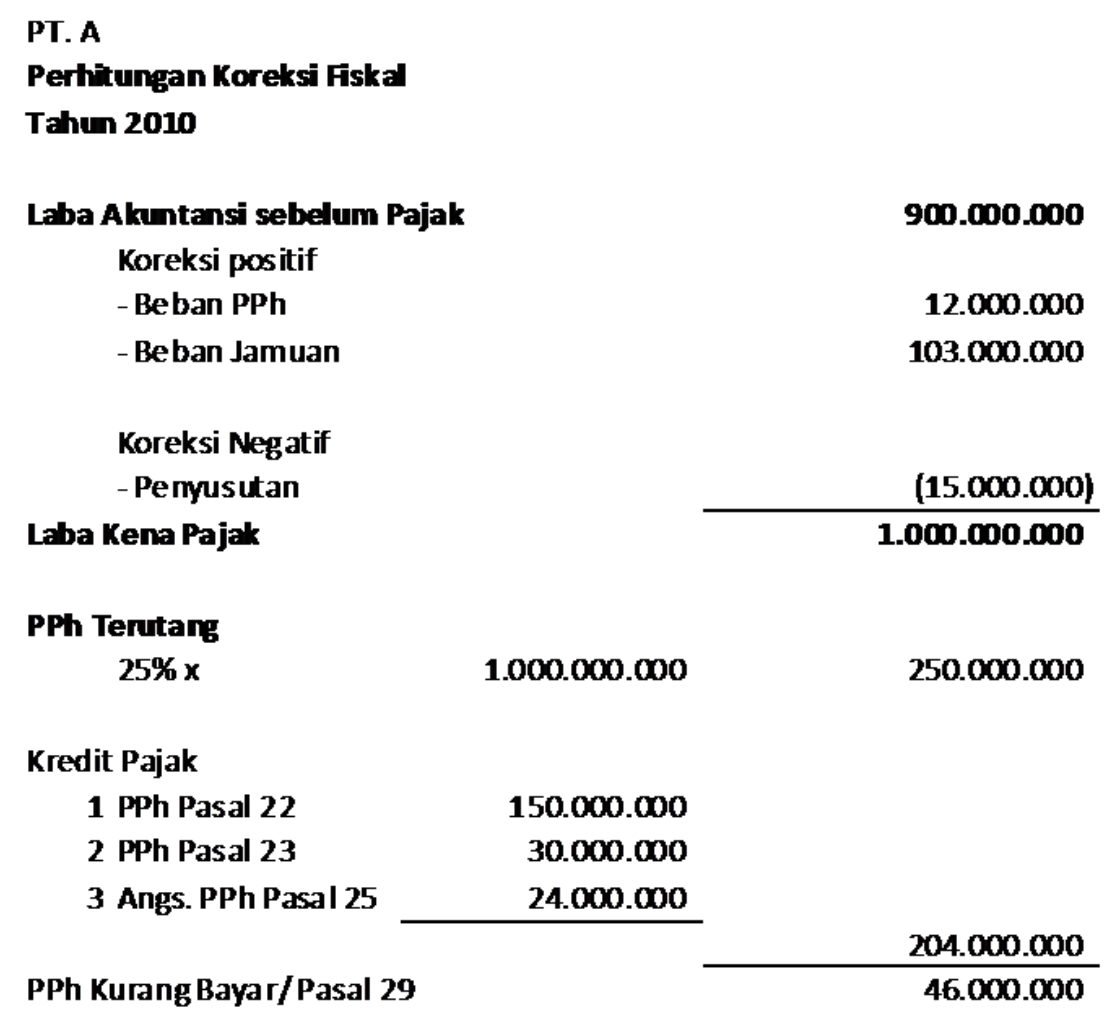

Gambar 2 Ilustrasi Perhitungan Koreksi Fiskal dan Kurang Bayar PPh Badan

Berdasarkan data hasil perhitungan koreksi fiscal dan PPh Badan Kurang Bayar Pada Akhit tahun maka, dibuat jurnal penyesuaian sebagai berikut:
(D) Beban Pajak Kini
Rp. 250.000 .000

(K) Uang Muka PPh Pasal 22

(K) Uang Muka PPh Pasal 23

(K) Uang Muka PPh Pasal 25

(K) Utang PPh Pasal 29
Rp.150.000.000

Rp. 30.000 .000

Rp. 24.000 .000

Rp. 46.000 .000

\section{KESIMPULAN}

Kegiatan pengabdian kepada masyarakat melalui Penyuluhan dan pendampingan ini telah direspon secara baik oleh peserta dalam diskusi. Beberapa kesimpulan yang diperoleh dari kegiatan penyuluhan ini adalah
1. Mahasiswa selama ini belajar akuntansi dan pajak secara parsial, sehingga mahasiswa menganggap akuntansi dan perpajakan sesuatu yang terpisah dan berdiri sendiri. Akuntansi untuk mencatat dan pajak hanya terkait perhitungan tariff pajak. 
2. Akuntansi Pajak Pertambahan Nilai terdiri dari 3 yakni akuntansi penyerahan $\mathrm{BKP} / \mathrm{JKP}$, akuntansi perolehan BKP/JKP dan akuntansi penyesuaian pada akhir bulan.

3. Akuntansi Pajak Penghasilan terdiri dari 2 yakni akuntansi pemotongan/ pemungutan dan akuntansi pajak penghasilan pada akhir tahun.

\section{UCAPAN TERIMA KASIH}

Dalam tulisan ini tim mengucapkan terima kasih dan apresiasi yang setingginya kepada pihak-pihak yang telah membantu terlaksananya kegiatan pengabdian ini, antara lain kepada:
a. Direktur Politeknik Negeri Sriwijaya
b. Ketua Pusat Penelitian dan Pengabdian Masyarakat (P3M) Polsri
c. Ketua Jurusan Akuntansi Polsri
d. Mahasiswa jurusan akuntansi Polsri

\section{REFERENSI.}

Undang-undang No. 36 tahun 2008 tentang Pajak Penghasilan 